Editorial

\title{
Port City Porosity: Boundaries, Flows, and Territories
}

\author{
Carola Hein \\ Chair of History of Architecture and Urban Planning, Delft University of Technology, The Netherlands; \\ E-Mail: c.m.hein@tudelft.nl
}

Submitted: 3 July 2021 | Published: 27 July 2021

\begin{abstract}
The introduction to this thematic issue on port city porosity sets the stage for the study of port city territories as a particular type of space, located at the edge of land and sea, built, often over centuries, to facilitate the transfer of goods, people, and ideas. It argues that the concept of porosity can help conceptualize the ways in which the spaces and institutions of ports, cities, and neighboring areas intersect. It expands on the well-established notion of the interface and more recent reflections on the port city threshold by arguing for a conceptualization of the port cityscape as a continuous network of port-related spaces and practices. The introduction places this reflection in time, exploring the ways in which boundaries have shifted and opened up; it also provides a brief overview of the 14 contributions to the thematic issue. The contributions are organized in three groups: (1) exploring long-term approaches to porosity in port city territories; (2) mapping and conceptualizing port city porosity on the sea side and on the land side; and (3) measuring, designing, and rethinking porosity in port city territories. The thematic issue opens questions for further research such as: Does the degree of porosity between port and city areas and the presence of maritime pockets in the city and the territory lead to greater resilience of port city activities? Does the existence of porous borders between port and city allow for easier transitions?
\end{abstract}

\section{Keywords}

borders; porosity; port cities; port cityscape; territories

\section{Issue}

This editorial is part of the issue "Planning for Porosity: Exploring Port City Development through the Lens of Boundaries and Flows" edited by Carola Hein (Delft University of Technology, The Netherlands).

(C) 2021 by the author; licensee Cogitatio (Lisbon, Portugal). This editorial is licensed under a Creative Commons Attribution 4.0 International License (CC BY).

\section{Introduction}

Port city territories have been built and administrated to facilitate flows of goods, people, and ideas between a maritime foreland and what is often a transnational hinterland. These flows depend on carefully curated tangible and intangible borders to guide the formation of spaces and social patterns that enable specific kinds of movement. These borders are often multilayered, as they permit passage of some elements while excluding others. Port city territories also serve as hubs for maritime activities, retaining port-related functions, knowledge, and imaginaries. They function like a porous sponge, selectively retaining, excluding, and dispensing. Planners delineate coasts and riversides to separate the spaces between water and land. Their interventions determine whether areas are dedicated to port, urban, or rural functions. Governance, policy-making, and plan- ning create and depend on tangible borders like security fences, and intangible boundaries, like legal systems, and land use patterns. The porosity of port city territories, the degree to which they facilitate flows and retain maritime activities, is thus at least partly the result of planning.

Port city territories have long attracted people and businesses that benefit from access to both sea and hinterland. These parties have accepted the negative externalities of port cities, such as the pollution of air, water, and land. Port functions are not limited to areas dedicated to port functions: ports rely on nearby cities and territories for their labor force, for the location of port-related companies and institutions, and for the social and cultural spaces needed for employees and their families. The maritime capital rankings that measure soft and hard infrastructure, but also components, such as access to the talent and services that are key 
to maritime businesses, give a sense of the importance of cities for ports (Menon, 2020). Contemporary urgencies open new possibilities for planning in port and city areas, for example, through the (re)creation of multifunctional spaces where port and city can mix, through the exploration of port influence throughout the territorythe port cityscape (Hein, 2019)-and by understanding how historical transformations have shaped current form and function. At a time of climate change, sea-level rise, and shifting coastlines, it is especially important to understand how porosity or its absence affects port city functioning over time.

This thematic issue's contributions conceptualize the role of borders in port cities through concrete case studies. The issue brings together diverse approaches to port, city, and territory through the lens of porosity. It explores the role of physical spaces and urban morphology from the waterfront to the region, with a focus on flows and borders and the institutional ways in which flows of goods, people, and ideas cross and populate port city territories. It examines the role of institutional settings and legal tools, exploring how new technologies, political and economic frameworks, and new safety regulations have reshaped the ways that port city territories guide flows and attract maritime activities. This introduction sets the stage by briefly exploring the concept of porosity, emphasizing the need for a spatial approach to understanding port city territories. It presents those territories as an interconnected port cityscape with particular spatial, institutional, social, and cultural challenges, before providing an overview and drawing connections between the contributions.

\section{Conceptualizing Porosity}

Porosity is a scientific term; it is also one that has been used in the context of urban planning. Encyclopedia Britannica states that "porosity reflects the capacity of soil to hold air and water" (Sposito, n.d.). This is directly linked to permeability, which describes the "ease of transport of fluids and their dissolved components" (Sposito, n.d.). The idea of porosity as openings in a solid space has appealed to urban scholars and planners. The concept of urban porosity was first used by Walter Benjamin in an essay with Asja Lacis in 1925 on Naples as a labyrinthic city with an underground filled with voids, a city where all the spaces are open to new interpretations and unexpected constellations, and where private activities are constantly intertwined with public ones (Benjamin \& Lacis, 1991).

Several scholars of the built environment have built on Benjamin and Lacis's impression of the porosity of Naples. The Greek architectural theorist Stavros Stavrides (2007, p. 174) has reflected on heterotopias and porosity, stating:

Urban porosity may be the result of such practices that perforate a secluding perimeter, providing us with an alternative model to the modern city of urban enclaves. A city of thresholds could thus represent the spatiality of a public culture of mutually aware, interdependent, and involved identities.

He underscores the importance in discussions of porosity of both space and time. The American sociologist Richard Sennett, in academic texts and popular press articles, has argued for open and porous cities (Sennett, 2010, 2015). Other authors have also reflected on porosity as a foundation for design (e.g., Wolfrum, 2018; Wolfrum \& Janson, 2019).

Many urban designers share the same viewpoint as the academics. For nearly two decades, Paola Viganò has been reflecting on the concept as a tool for both the analysis of urban space and its design (Viganò, 2018). Dutch urban planning scholars Igor Moreno Pessoa, Tuna Tasan-Kok, and Willem Korthals Altes and colleagues summarize the multiple approaches to porosity, inquiring into its usefulness in terms of urban resilience in the context of Brazil, and they have created a porosity index (Pessoa et al., 2015). They propose that porous areas/voids such as "disconnected neighborhoods, brownfield areas and leftover places... can be captured by the metaphor of urban porosity" and "that these areas can provide capacity for flexibility, fluidity and absorption in major cities, but that they can also be a source of fragmentation, disconnection and isolation between different social groups....Porosity may thus have both positive and negative influences on the resilience of urban systems" (Pessoa et al., 2015, p. 47). Designers have followed up on these approaches: for example, a team around Winy Maas investigates porosity in architectural design (Maas et al., 2018). Cristian Moreno, architect of the city-port of Valparaíso, inspired by planning in Palermo, has applied the concept of the water edge (Figure 1).

The focus on porosity in urban studies can be seen as a way to overcome the modernist separation of functions and the introduction of hard boundaries between specific spaces that have led to the increase of traffic and socio-economic segregation. Yet, so far, the existing literature does not explore the theme of porosity in light of big industrial entities such as ports or evolving port city territories. This thematic issue argues that the concept of porosity can aid understanding of how sea and land, and port, city, and hinterland have interconnected over time. It asks whether the size, tightness, and durability of maritime pores and their permeability in a port city territory can predict adaptability in times of transition. Does the degree of porosity, the number of openings in dykes, the presence of maritime pockets in the city, and the territory lead to greater resilience of port city activities? Does the existence of porous borders allow for easier transitions?

Port investments often occur over long periods of time, leading to lock-in effects, to use path dependence terminology (Hein \& Schubert, 2021). Understanding 


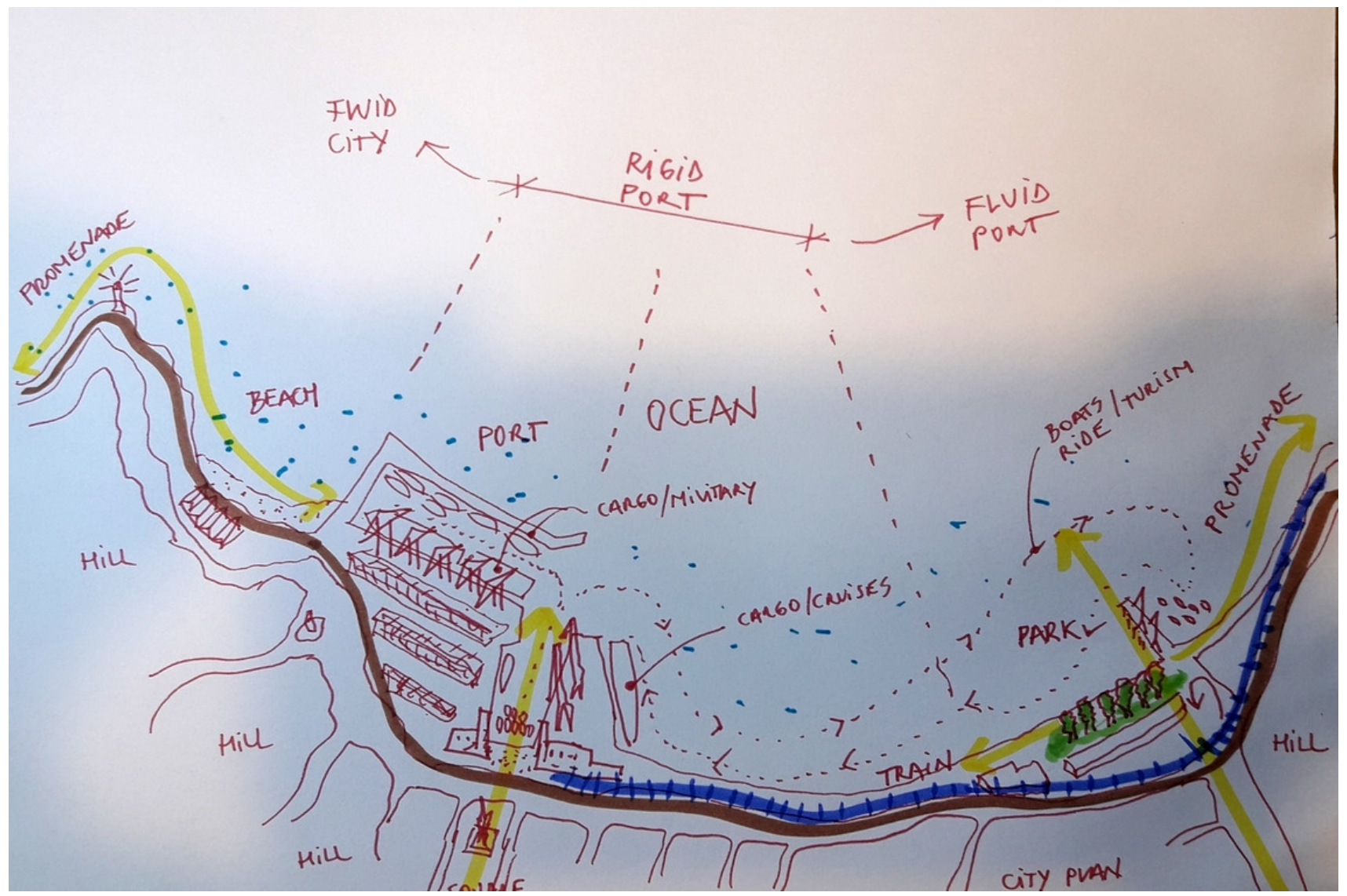

Figure 1. Mental map of the port city of Valparaíso by Cristian Moreno, made for the online course "(Re)Imagining Port Cities." Source: Courtesy of Cristian Moreno.

long-term developments and histories is key to transforming spaces and institutions and ultimately designing future port city territories. As specific areas have become dedicated to port functions, they are locked in and hard to change. Large warehousing, petroleum storage, and industrial areas do not allow easy integration with other functions. Designing and planning smaller spaces for the intermingling of maritime functions can improve the interconnectedness of port and city, and facilitate much needed transitions in line with energy and other concerns. In fact, smaller port cities may be places where change occurs first. Are smaller port cities also smarter port cities?

\section{Porosity and Conceptions of Port City Territory: Interface, Threshold, and Port Cityscape}

The concept of porosity can help conceptualize the ways in which port, city, and territory interact. It can also help expand on the well-established notion of the interface. The notion of the port-city interface has been helpful in understanding spaces such as urban waterfronts, where port and city interests overlap and often conflict (Daamen \& Louw, 2016; Daamen \& Vries, 2013; Hayuth, 1982; Hein \& van Mil, 2020; Hesse, 2018; Hoyle, 1989; Hoyle et al., 1988). It has been less helpful in understanding the spatial, social, and cultural implications of port city territories in their complexity. Literature on porosity also relates to the topic of thresholds, a key element in the contributions of Beatrice Moretti (2019, 2020) This threshold character is closely linked to the concept of porosity and requires rethinking the boundaries between and the planning of ports and cities.

In port city territories, port and city engage in multiple ways, not just along a single thin line, a clearly visible fence. In fact, the border between port and city has openings, and many elements cut across air and water. Port city functions form networks in space, interlinked by physical infrastructures and administrative, financial, and other chains of power. These networks change over time in scale and size and even usage. We need a clearer understanding of how these networks evolve, how boundaries are pushed and porosity is transformed over time and through intangible tools such as those of planning, polity, and law, but also as a result of cultural transformations and imaginaries.

The port cityscape is discontinuous and not clearly bounded. Most of the current literature, however, considers the port a clearly bounded entity. This perception tends to ignore the many ways ports use spaces on sea and land. Many contemporary ports are surrounded by high fences and controlled by special institutions, but their spatial footprint-through infrastructure, warehousing, and logistics networks-as well as their 
environmental impact-for example, air, water, soil, and noise pollution-extends far beyond the port's demarcated borders and into neighboring cities and regions. The result is a port cityscape, a networked space that extends from land to sea, including ships and pipelines, port facilities and warehouses, industrial and logistic structures, headquarters and retail buildings, but also housing and leisure facilities. This port cityscape is administrated, planned, imagined, and represented by multiple institutions and rarely as part of a shared vision. The separate consideration and planning of all these entities leads to a segregated planning approach to waterfront revitalization or river and coastline development, even though water connects all of these spaces. The segregation of planning is reflected in how these sites are represented: Port authorities will write and depict the port city and the water in a different way than a city or regional institution (Hein, 2016; Figure 2).

Port city territories consist of a global foreland and a deep hinterland. The collective governance of these extensive landscapes and the logistics of the multiple flows and the multi-layered use of space in these regions require careful analysis and development. The spaces of port functions-and spaces related to port functionsare thus entangled with and sometimes shared with those the city uses. This new territorial and institutional scale must be theorized and studied in a methodological manner with a focus on governance systems that can contribute to a redefinition of port-city-region relationships. Such a reconceptualization is urgently needed at a time when port city regions around the world face a number of complex problems that require integrated spatial and social planning and design measures for use of this limited space. Port and city (and territory) must be able to evolve jointly. Buy-in from local stakeholders is necessary to facilitate the construction of hard infrastructures necessary for the functioning of the port, for acceptance of the side effects of ports (noise, security, emissions), but also to develop the skillsets and technologies needed for the port and port city of the future. Each city is different in terms of geography, spatial form and function, history and culture; the way a city's government responds will be linked to long-term path dependencies that impact future development.

\section{Porosity in Time: Pushing Boundaries, Opening Boundaries}

Historically, port and city have been intimately intertwined in many cities around the world. Medieval cities such as Amsterdam, Venice, and Hamburg stand as examples. Images by Braun and Hogenberg from Civitates Orbis Terrarum (1572-1612) show the number of ships in the heart of cities at the time and the unique typology of buildings that are accessible on one side by water and the other by land (Figure 3). Ships could unload directly into the warehouses on the waterside, administration is located close to the street side of the house, and living took place above and between these maritime functions. The house itself has historically been a porous border for port-related activities. The surrounding city hosted numerous spaces where maritime activities occurred and where people from different trades mingled. Among these urban cells were also spaces of migration and temporary use-Chinatowns, red light districts, sailor towns-that allowed for rapid transitions. Stock exchanges, but also coffee shops where traders discussed the fate of ships and shipping and where workers had their breaks are part of such a porous space. Market places provided room for the exchange and landing of goods.

With industrialization, the size of the maritime pores changed. Ports emerged as separate, ever larger units, with fewer and more select openings toward their

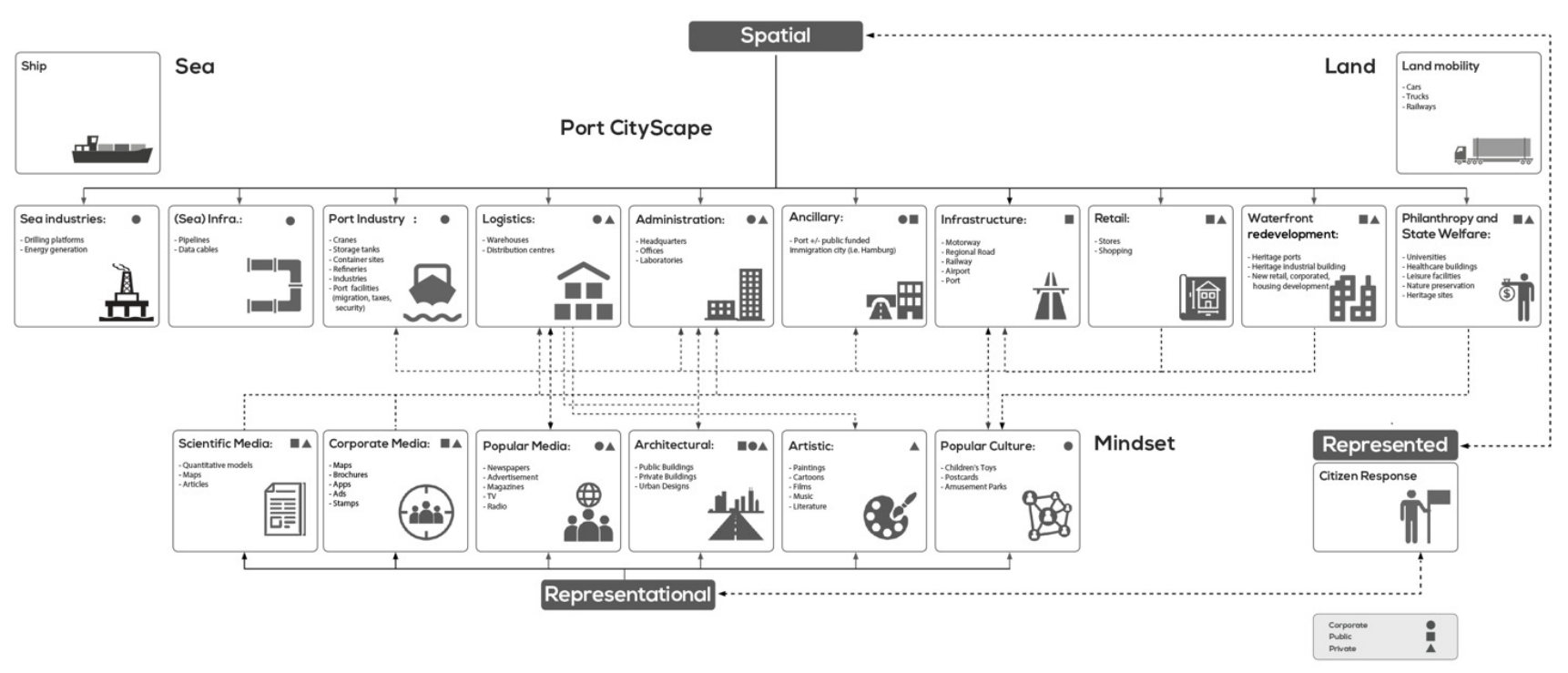

Figure 2. Port cityscape. Source: Carola Hein. 


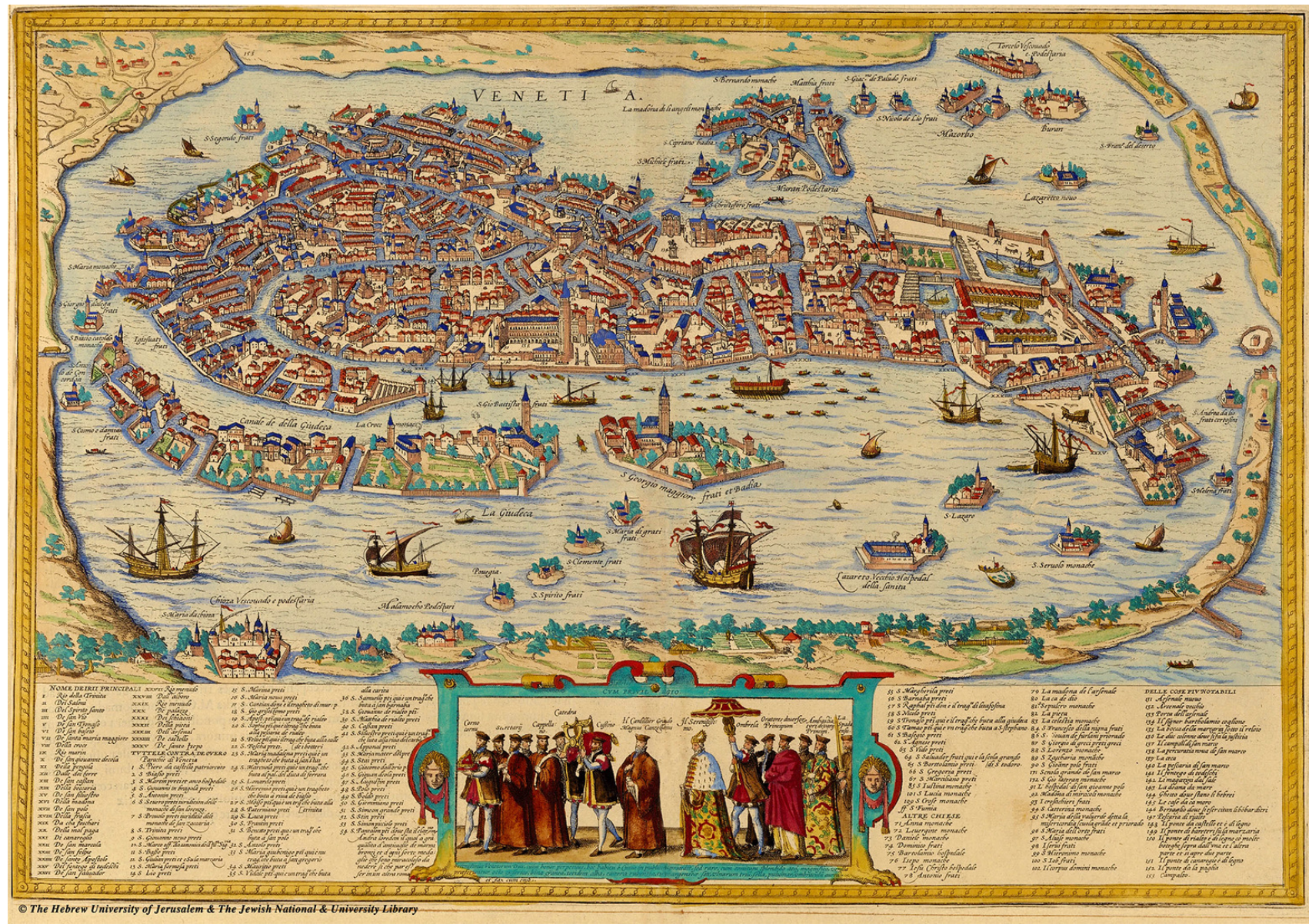

Figure 3. Map of Venice, 1572, by Georg Braun and Frans Hogenberg. Source: Hogenberg (1572).

environment. Safeguarded spaces of transshipment and warehousing facilitated the throughput of goods, rather than the port's integration into the nearby territory. First warehouse districts, then office districts, and occasionally dedicated housing areas became homes for maritimerelated functions. Administrative districts such as the Kontorhaus district in Hamburg are icons of these growing mono-functional pores in the tissue of the city. Gates to port districts and some other multifunctional public places have continued to serve as sites of exchange.

With containerization, this maritime intermingling in public spaces disappeared; in fact, the spaces themselves often disappeared. Ports became largely independent entities built for the speedy transmission and refining of goods, and for the transport of people. Cities transformed abandoned and formerly fenced-off port areas into urban waterfronts, creating new openings. Meanwhile, cities focused on addressing local economic, social, and other issues, often paying little attention to the needs and interests of the modern port nearby. As ports battled to rise in the rankings of better and faster, urban maritime activities largely disappeared, or became very specialized and largely invisible. Yet, the attention to the role and ranking of leading maritime capitals (Menon, 2020) suggests a growing need for port city intersection and collaboration. To create more permeability for transmission to the hinterland, we have created larger cells and higher flows in the port area, while limiting the permeability and exchange with the surrounding city and territory. This has meant the port has less value for the city and decreased resilience.

At a time of sea-level rise, designers and politicians are arguing for sponge cities (e.g., Zevenbergen et al., 2018) - cities and territories that can store water in the soil to avoid flooding. Cities around the world are developing new architectural structures that respond to rising sea levels. In the HafenCity Hamburg for example, the ground floor of the new buildings erected behind the dyke can be shut off with flood gates, while people can escape the area via pedestrian bridges. Meanwhile, ever higher dykes, such as along the Elbbrücken area, have been transformed on both sides into stepped terraces that allow strolling, outdoor activities, and sitting on the edge of the city overlooking the port. We wonder: Could we borrow sponge-thinking to imagine port cities as sponges for maritime activities, places where we can create a new water awareness among politicians and citizens and where the ports of the future are designed as places that benefit all stakeholders involved (and not only a few select decision makers)? 


\section{Overview of the Thematic Issue Contributions}

This thematic issue on porosity in port city territories brings together a broad range of scholars, both young and established, to explore a wide range of time periods, spaces, scales, and conceptualizations, discussed in case studies from Europe, America, Asia, and Africa. The contributions raise numerous questions about the object of study: Do we focus on a specific zone between sea and land, port and city, an interface, or does the concept of porosity allow us to look beyond the waterfront to explore the presence of maritime pockets throughout the city and region, in line with the concept of the port cityscape? The texts are organized in three groups, respectively engaging with: (1) histories of porosity in port city territories; (2) mapping and conceptualizing port city porosity on the sea side and on the land side; and ( 3 ) measuring, designing, and rethinking porosity in port city territories.

\subsection{Porosity in Port City Territories Through Time and Space}

Porosity in port city territories has changed over the centuries as spaces of transshipment, warehousing, urban form, and transportation evolved; as political, institutional, and economic frameworks have changed; and as new technologies have emerged. Relationships among diverse port city stakeholders-governments, corporations, maritime companies, and citizens-change over time in ways that are visible in spatial, social, and cultural transformations.

Using mapping-based research and examining population shifts around the North Sea since the medieval period, Yvonne van Mil and Reinout Rutte (2021) describe port cities as entrance nodes to large hinterlands. In a series of demographic maps, they show how social and spatial shifts around the North Sea were heavily influenced by sea-based developments.

How flows of goods shape a port city territory is the focus of the exploration of the Gdańsk region by Karolina A. Krośnicka, Piotr Lorens, and Eliza Michałowska (2021). Starting with the 11th century, the authors examine the influence of politics, economic investments, and infrastructure developments on the evolving forms and the changing borders of diverse types of port cities in the larger region.

Keren Ben Hilell and Yael Allweil (2021) explore questions of infrastructure and waterfront transformation in Haifa since the mid-18th century. They focus on the role that changing commodities have had on port transformations and the way these have been pushing the borders of ports. They trace the changes in the port city as a history of "porosity and intangibility," shifting away from a focus on histories of empire, colonialism, nationalism, and globalization to one exploring the role of transported goods, directions of flows, and technological transformations.
Stephan Hauser, Penglin Zhu, and Asma Mehan (2021) explore port city porosity through the historic development of a single commodity: oil in the port city of Dunkirk since the 19th century. They focus on safety threats emanating from petroleum sites through fires and pollution, and they reflect on the necessary distancing of industrial sites and housing areas as one expression of porosity in industrial cities with shifting boundaries between residential and industrial areas.

The regional dimension of ports is also emphasized by Hernán Cuevas Valenzuela, Jorge Budrovich Sáez, and Claudia Cerda Becker (2021). With the case of Valparaíso, they explore the political process behind neoliberal restructuring and the controversies it has generated. Using an ethnographic approach, the chapter explores labor relationships, social conflicts, and representations of the port city relationship.

\subsection{Mapping Porosity on the Sea Side and on the Land Side of Port and City}

Understanding the spaces of porosity in port city territories requires appropriate tools and methodologies to study the physical structure of the waterfront, the shape of the quay walls, and other access points between sea and land in light of changes over time and to design them. This group of articles demonstrates how port city porosity evolves as borders are constructed, broken down, and rebuilt, continuously creating new patterns of engagement between port, city, and territory.

Justyna Breś and Karolina A. Krośnicka (2021) explore water-land porosity by tracing the water edge of the Motława River over 1000 years. Assessing the height difference between water and land, the type of slope, and the form of man-made structures and overhangs, they establish categories for assessing porosity that can be more widely used to understand multiple forms and functions of water-land relationships. These categories are particularly important for understanding the complexity of this edge space and opportunities for urban design at a time of climate change.

María J. Andrade, João Pedro Costa, Eduardo Jiménez-Morales, and Jonathan Ruiz-Jaramillo (2021) take a long-term morphological view of Malaga and explore the city's evolution from the 8th century to the present through a spatial analysis of port-related spaces and nodes, emphasizing spaces of physical, functional, and social porosity over time. The authors show how barriers are broken over time and rebuilt, creating new balances and patterns including in regard to contemporary challenges such as cruise ship tourism. They point both to spatial and social porosity, arguing for the opening up of spaces between port and city.

Khalil Bachir Aouissi, Said Madani, and Vincent Baptist (2021) similarly take a long-term and spatial approach, but they do so through the study of Algiers from the 16th century until today. Using a morphological analysis of the port-city interface, they identify a 
changing albeit persistent divide between port and city territories. Examining the evolving focus of port activities and their impact on the threshold area through four periods, they explore shifting spatial adaptations.

Lucija Ažman Momirski, Yvonne van Mil, and Carola Hein (2021) add another perspective to the exploration of spatial patterns in and around port cities, focusing on land use patterns in Hamburg, Rotterdam, and Koper over the last 500 years. Although ports may appear to have a clear border with high fences, environmental impacts, for example, shape land use decisions on both the city side and the port side. As the functions of the port and the city change, land use porosity can provide opportunities for innovative design ideas to arise in areas where port and city coexist.

\subsection{Measuring, Rethinking, and Designing Porosity}

Introducing the concept of porosity to the study of port city territories requires careful reflection on conceptualization, appropriate tools, and methodologies. These case studies can help in the development of a toolbox that allows mixed-methods research to be combined with design interventions and the development of adaptation strategies for future urban planning. The third group of articles explores port city porosity through interviews, company data, design, and the impact of the energy transition.

Yueyue Zhang and Peter Martin Ache (2021) take a conceptual approach to porosity arguing that port cities are capable of pushing their tangible and intangible boundaries. They use the concept of 'penumbral' to examine the case of the Shanghai Baoshan port-city interface. Through first-hand interviews, they study perceptions of local stakeholders, port-related values, and concepts. They argue that such a nuanced approach to tangible and intangible boundaries can advance planning practice for the integration of port and city.

Working at the scale of the waterfront, Maurice Jansen, Amanda Brandellero, and Rosanne van Houwelingen (2021) examine how former port districts in Rotterdam-Merwe Vierhavens and RDM Shipyardshave adapted to the departure of some port functions and have been reused for urban and mixed-use activities. They study flows of users in and out of the area and analyze the companies and institutions currently located in these transformed port city spaces. They offer insights into the district's emerging uses and imaginaries, showing the resilience and adaptation of port legacies.

A better understanding of porosity can also facilitate citizen engagement and design. Drawing on research projects and design studios with students from Tongji University, Harry den Hartog (2021) explores the role of urban labs in the urban regeneration of Shanghai's former industrial waterfronts. Using questionnaires and interviews to understand the use and appreciation of the new public space and buildings, the article explores the role of densification and the reuse of urban elements in the context of high-density investment and development projects.

Lukas Höller (2021) highlights both positive and negative potential effects of exchanges between port and city and focuses on the role of "design fiction" as a tool for improving port-city relationships. Through the case of a design project for the town of Kirkenes in northern Norway, destined to become a seaport on the Arctic route, he explores a floating port, a reindeer-energy port, an urban port, and a wetland port as typologies for future port cityscapes.

To round out the thematic issue, Stephen Ramos (2021) uses the concept of porosity in a speculative proposal for a transitional dome district in what he calls the "seam space" between port and city. As part of the global energy transition, wood pellets are increasingly used for heating. Pellet volatility requires appropriate warehousing, which has led to new building typologies. The article considers the emergence of new energy spaces and the transforming of port city space as it invites politicians and planners to acknowledge material changes in the development of new urban concepts.

\section{Acknowledgments}

The idea for this thematic issue has evolved from discussions in the PortCityFutures Centre of the Leiden-DelftErasmus University consortium.

\section{Conflict of Interests}

The author declares no conflict of interests.

\section{References}

Andrade, M. J., Costa, J. P., Jiménez-Morales, E., \& Ruiz-Jaramillo, J. (2021). A city profile of Malaga: The role of the port-city border throughout historical transformations. Urban Planning, 6(3), 105-118.

Aouissi, K. B., Madani, S., \& Baptist, V. (2021). Morphological evolution of the port-city interface of Algiers (16th century to the present). Urban Planning, 6(3), 119-135.

Ažman Momirski, L., van Mil, Y., \& Hein, C. (2021). Straddling the fence: Land use patterns in and around ports as hidden designers. Urban Planning, 6(3), 136-151.

Ben Hilell, K., \& Allweil, Y. (2021). Infrastructure development and waterfront transformations: Physical and intangible borders in Haifa port city. Urban Planning, 6(3), 43-57.

Benjamin, W., Lacis, A. (1991). Denkbilder: Neapel [Thought images: Naples]. In T. Rexroth (Ed.), Walter Benjamin, Kurze Prosa, Gesammelte Schriften [Short prose: Collected writings] IV-1/2. Suhrkamp Verlag.

Breś, J., \& Krośnicka, K. A. (2021). Evolution of edges and porosity of urban blue spaces: A case study of Gdańsk. Urban Planning, 6(3), 90-104. 
Cuevas Valenzuela, H., Budrovich Sáez, J., \& Cerda Becker, C. (2021). Neoliberal economic, social, and spatial restructuring: Valparaíso and its agricultural hinterland. Urban Planning, 6(3), 69-89.

Daamen, T. A., \& Louw, E. (2016). The challenge of the Dutch port-city interface. Tijdschrift voor Economische en Sociale Geografie, 107, 642-651.

Daamen, T. A., \& Vries, I. (2013). Governing the European port-city interface: Institutional impacts on spatial projects between city and port. Journal of Transport Geography, 27, 4-13.

den Hartog, H. (2021). Shanghai's regenerated industrial waterfronts: Urban lab for sustainability transitions? Urban Planning, 6(3), 181-196.

Hauser, S., Zhu, P., \& Mehan, A. (2021). 160 years of borders evolution in Dunkirk: Petroleum, permeability, and porosity. Urban Planning, 6(3), 58-68.

Hayuth, Y. (1982). The port-urban interface: An area in transition. Area, 14(3), 219-224.

Hein, C. (2016). Writing port cities. PORTUS, 2016(31). http://portusonline.org/writing-port-cities

Hein, C. (2019). The port cityscape: Spatial and institutional approaches to port city relationships. PortusPlus, 8. https://portusplus.org/index.php/pp/article/ view/190/187

Hein, C., \& Schubert, D. (2021). Resilience and path dependence-A comparative study of the port cities of London, Hamburg and Philadelphia. Journal of Urban history, 47(2), 389-419. https://doi.org/ 10.1177/0096144220925098

Hein, C., \& van Mil, Y. (2020). Mapping as gap-finder: Geddes, Tyrwhitt, and the comparative spatial analysis of port city regions. Urban Planning, 5(2), 152-166.

Hesse, M. (2018). Approaching the relational nature of the port-city interface in Europe: Ties and tensions between seaports and the urban. Tijdschrift voor economische en sociale geografie, 109(2), 210-223.

Hogenberg, F. (1572). Civitates Orbis Terrarum, Vol I, 1572 [Cities of the world, Vol. I, 1572]. Kempen. https://commons.wikimedia.org/wiki/File:Venetia_ 1572.jpg

Höller, L. (2021). Porous Kirkenes: Crumbling mining town or dynamic port cityscape? Urban Planning, 6(3), 197-209.

Hoyle, B. S. (1989). The port-city interface: Trends, problems and examples. Geoforum, 20(4), 429-435.

Hoyle, B. S., Pinder, D. A., \& Husain, M. S. (Eds.). (1988). Revitalising the waterfront: International dimensions of waterfront redevelopment. Belhaven Press.

Jansen, M., Brandellero, A., \& van Houwelingen, R. (2021). Port-city transition: Past and emerging sociospatial imaginaries and uses in Rotterdam's Makers District. Urban Planning, 6(3), 166-180.
Krośnicka, K. A., Lorens, P., \& Michałowska, E. (2021). Port cities within port regions: Shaping complex urban environments in Gdańsk Bay, Poland. Urban Planning, 6(3), 27-42.

Maas, W., Ravon, A., \& Arpa, J. (2018). PoroCity. nai010.

Menon, A. (2020). The leading maritime capitals of the world: 2019. Menon Economics and DNV GL Publication.

Moretti, B. (2019). Governance patterns on the urbanport threshold: The emergence of the city of the cluster. PortusPlus, 8(1), 1-17.

Moretti, B. (2020). Beyond the port city: The condition of portuality and the threshold concept. Jovis.

Pessoa, I. M., Tasan-Kok, T., \& Altes, W. K. (2015). Brazilian urban porosity: Treat or threat? Urban Design and Planning, 169, 47-55.

Ramos, S. J. (2021). Materiality in the seam space: Sketches for a transitional port city dome district. Urban Planning, 6(3), 210-222.

Sennett, R. (2010). The public realm. In G. Bridge \& S. Watson (Eds.), The Blackwell city reader (pp. 261-272). Blackwell.

Sennett, R. (2015, November 27). The world wants more 'porous' cities-so why don't we build them? The Guardian. https://www.theguardian.com/cities/ 2015/nov/27/delhi-electronic-market-urbanistdream

Sposito, G. (n.d.). Soil. Encyclopedia Britannica. https:// www.britannica.com/science/soil

Stavrides, S. (2007). Heterotopias and the experience of porous urban space. In K. Franck \& Q. Stevens (Eds.), Loose space. Possibility and diversity in urban life (pp. 174-192). Routledge.

van Mil, Y., \& Rutte, R. (2021). Urbanization patterns around the North Sea: Long-term population dynamics, 1300-2015. Urban Planning, 6(3), 10-26.

Viganò, P. (2018). Porosity: Why this figure is still useful. In S. Wolfrum (Ed.), Porous city: From metaphor to urban agenda (pp. 50-56). Birkhäuser. https://doi. org/10.1515/9783035615784-009

Wolfrum, S. (2018). Porous city: From metaphor to urban agenda. Birkhäuser.

Wolfrum, S., \& Janson, A. (2019). Porosität-über Durchdringung [Porosity-About fusion]. In S. Wolfrum \& A. Janson (Eds.), Die Stadt als Architektur [The city as architecture] (pp. 91-98). Birkhäuser. https://doi. org/10.1515/9783035618037-014

Zevenbergen, C., Fu, D., \& Pathirana, A. (Eds.). (2018). Sponge cities: Emerging approaches, challenges and opportunities [Special issue]. Water, 10(10).

Zhang, Y., \& Ache, P. M. (2021). Tangible and intangible boundaries: The Case of Baoshan port-city interface in Shanghai. Urban Planning, 6(3), 152-165. 


\section{About the Author}

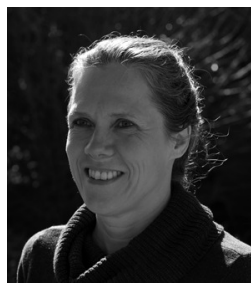

Carola Hein is Professor of History of Architecture and Urban Planning at Delft University of Technology. As well as major grants, she has received a Guggenheim and an Alexander von Humboldt fellowship. Her books include Oil Spaces (2021), Adaptive Strategies for Water Heritage (2019), The Routledge Planning History Handbook (2018), Reflections on Urban, Regional and National Space (with Uzō Nishiyama, 2017), Port Cities (2011), Cities, Autonomy and Decentralisation in Japan (2006), The Capital of Europe (2004), Rebuilding Urban Japan after 1945 (2003), and Hauptstadt Berlin 1957-58 (1991). 